\title{
The Effect of Exchange Rate Change on the Price of the Most Important Vegetable Crops in Egypt
}

\author{
[Reyad Ismaeil Moustafa ,Mamdouh Elbadry Mohamed]
}

\begin{abstract}
This research aims to study the impact of changing the exchange rate on the retail prices of the most important vegetable crops in Egypt ( onions, garlic, tomatoes , peas , green zucchini , green beans, potatoes , cucumbers ), by calculating the impact of the change in the exchange rate on the evolution of retail prices of the most important vegetable crops under study ( the effect of scrolling ), and develop a model (VAR) standard is structured to measure the impact of the change in the exchange rate on the retail prices of the most important vegetable crops in question. the correlation between the exchange rate of the Egyptian pound against the U.S. dollar and retail prices has been calculated of the most important vegetable crops in Egypt during the period from (January 2010 until December 2014) through the study of the effect of scrolling of the exchange rate on the prices of those crops, and the results showed the existence of a correlation between the exchange rate and the prices of those crops at the level of significance 0.01 , which means that the change in the exchange rate of the dollar against the pound offset change extrusive in the prices of the most important vegetable crops amounted to about $(4.4,11.6,3.6,2.7,0.4$, $4.3,1.4,1.13$ ) for onions, garlic , tomatoes, green peas, zucchini, green beans, potatoes, cucumbers, respectively.

The study has been using self- regression model (VAR) to analyze of the relationship between the exchange rate and prices of the most important vegetable crops in Egypt, where the results found the clarity and strength of the relationship between the exchange rate and prices of the most important vegetable crops in Egypt. Have used the function to respond to shocks to identify the extent of the impact of prices of major food commodities in Egypt during the period (January 2010 until December 2014) shocks, which can be exposed to the exchange rate, it was found that any shock in the exchange rate were the effects incremental retail prices for all crops studied, and this is what explains the impact of the global financial crisis on the continuing rise in world food prices and the impact on food prices in the Egyptian market, particularly retail prices for vegetable crops in the Egyptian market .
\end{abstract}

Authors Name/Reyad Ismaeil Moustafa (Author) line1: Agricultural College / Suez Canal University line2: Egypt

Authors Name/ Mamdouh Elbadry Mohamed (Author)

line1: Institute of Agricultural Economic Research / Agricultural Research Center

line2: Egypt
In the light of study results, the research recommends the following:

(1) Expansion in the production of crops in Egypt, so that it can rise at rates self-sufficiency in order to avoid the adverse effects of exchange rate changes on domestic prices rise .

(2) Find foreign markets for vegetable crops (onions, garlic, tomatoes, peas, green zucchini, green beans, potatoes, cucumbers), specially that Egypt enjoys some comparative advantages in the production of these crops, and to benefit from the increase in the price of the dollar and then increase the outcome of the state of foreign exchange .

(3) The need to follow monetary policies aimed at reducing the high exchange rate, especially with the prices of vegetable crops affected by the subject of the study to increase the exchange rate.

Keywords- Pass Through Effect, Vector Auto Regression, Granger Causality, Akaike Information Criterion, Schwarz Bayesian Criterion, Augmented Dickey,Fuller, Lag Structure, Lag Exclusion, Cross Correlation, Impulse Response .

\section{Introduction}

The world has witnessed a global financial crisis since September 2008 threatened the recession of the world economy and especially the economies of developing countries which depends on the rich countries. Then it moved from being a crisis, a financial crisis to turn into an economic crisis in the light of the case of the Great Depression that led to the aggravation of the crisis of unemployment in addition to other social crises, where the impact of the global crisis began to appear in developing countries, especially Egypt, the decline in the economic growth rate to less than $2 \%$ during 2014 compared to about $7.7 \%$ in 2008 , in addition to the decrease in the value of Egyptian exports as a result of recession largest markets importers from Egypt, the United States of America and the European Union, where occupy strong at about $65 \%$ of the Egyptian exports , where decreased value of total Egyptian exports from about 143.03 million EP in 2008 to approximately 134.9 million EP in 2009 by a decline of about $5.7 \%$ from its value in 2008 , while it decreased the value of Egyptian agricultural exports from about 13.1 million EP in 2008 to about 11.3 million EP in 2009 amounted to a decrease of approximately $13.7 \%$ from their year 2008, and the decrease in the volume of foreign direct investment of about 13.24 billion U.S. dollars in 2007 to about 2.08 billion U.S. dollars in 2014, specially private investment goes to agriculture sector.

The global financial crisis has led to a continuous rise in world food prices, which reflected the impact on food prices in the Egyptian market, which saw prices of agricultural crops, 
has increased considerably, especially the prices of vegetable and fruit crops.

The problem that is the global of financial crisis led to increase world food prices and the impact of some economies of developing countries, including Egypt, where affected in the volume of foreign trade and balance of trade, where the value of total Egyptian exports decreased from about 15.98 billion EP in June 2008 to about 8.83 billion EP in December 2008 with a decrease rate reached about 7.2 billion EP, accounting for about $44.7 \%$ of the value of total exports in June 2008, then increased to about 10.12 billion EP in September 2009 , the rate of increase was about 1.3 billion $\mathrm{EP}$, accounting for about $14.6 \%$ of the value of total exports in June 2008. While the total value of imports was less affected by the global financial crisis, which saw the total value of Egyptian imports decreased from about 29.23 billion EP in August 2008 to about 19.79 billion EP in December 2008 with a decrease rate reached about 9.4 billion EP, accounting for about $32.3 \%$ of the value of total imports in August 2008 , then continued to decline to reach about 18.76 billion EP in September 2009 , a decrease rate reached about 1.03 billion EP, presenting about $5.2 \%$ of the value of total imports in August 2008. As the product of foreign exporter to the Egyptian market depends in production on its national currency, which made him shift the burden of the change in the value of imports from intermediate goods and consumer to importer Egyptian, the financial crisis led to rise in the value of the dollar against the Egyptian pound, which increased the dollar exchange rate from about 5.4 EP / dollars in March 2008 to about 7.4 EP / dollars in March 2014 , which in turn reflected on the cost of factors of production and the prices of commodities and Egyptian crops, rising average prices of vegetable crops from 2008 to 2014 an increase of respectively $206.3 \%, 329 \%, 114.5 \%, 117.9 \%, 53.0 \%, 155.8 \%$, $135.9 \%, 86.6 \%$ of the crops (onions, garlic , tomatoes, peas , green zucchini, green beans, potatoes, cucumbers ), and hence the importance of studying the impact of the change in the exchange rate of change in the prices of crops specially Egyptian vegetable crops, which has necessitated the study of the effect of exchange rate change on the prices of the most important vegetable crops in Egypt .

The main objective of the research is studying the impact of changing the exchange rate on the prices of the most important vegetable crops in Egypt and presented in ( onions, garlic , tomatoes, peas, green zucchini, green beans, potatoes, cucumbers ) and that by achieving the following objectives: (1) study the evolution of exchange rates and the prices of the most important vegetable crops in Egypt during the period (2000-2014) , (2) calculate the impact of the change in the exchange rate on the evolution of prices of the most important vegetable crops in Egypt ( scroll effect ), and (3) Develop a regression model is self- structured (VAR) Vector Auto Regression to analyze the relationship between the exchange rate and the prices of the most important vegetable crops in Egypt, by calculating the correlation between the exchange rate of the Egyptian pound against the U.S. dollar and the prices of crops under study during the period (January 2010 until December 2014) through the study of the impact of scrolling (Pass - Through Effect)) of the exchange rate on the prices of these crops in Egypt .

The search depends on the use of statistical analysis tools and econometric where test was used the correlation between variables Cross correlation, the effect of scrolling, test Granger Causality, a statistical test is used to make sure ( the existence of a causal relationship reciprocal any discovery of internal variables vessels, $r$ Test the relationship false Spurious any no causal relationship, or test a causal relationship in one direction ), Test unit roots unit Root Test, a statistical test is used when there is a correlation autonomy for the period reactionary first Ac (1) and is also used to ensure the stability of the smooth temporal and uses the following tests (Augmented Dickey-Fuller Test and Phillips - Perron Test), the test of lag length including (Schwarz Bayesian Criterion (SBC),Akaike Information Criterion (AIC) and Likelihood Ratio (LR) are used for comparison between the two types of estimates in a number of variables or parameters especially in determining the number of delays, and regression testing of self- Vector Auto Regression Test (VAR) is a model of structural equations is used as an alternative to predict the dynamic of the internal variables static data only. The research was based primarily on data from published and unpublished at the Central Agency for Public Mobilization and Statistics, bulletins and Central Bank of Egypt in addition to the bulletins central administration of the agricultural economy.

\section{Research results and discussion}

The evolution of the retail prices of the most important vegetable crops in Egypt during the period (2000-2014):

A review of the results (Table 1) that the exchange rate taken a general trend growing annually by about as much as 0.21 Egyptian pound presents about $4.0 \%$ for the average of about 5.42 , while showing that the price of onions taken a growing trend -year annual rate of about 0.31 presents about $16.1 \%$ for average of about 1.91 , it turns out that the price of garlic taken the general trend was increasing annually, about 0.71 presents about $12.8 \%$ from the average of about 5.51 , while showing that the price of tomatoes taken a growing trend yearold reached about 0.19 presents about $10.7 \%$ for the average of about 1.8 , it turns out that the price of green peas taken a general trend growing annually by about as much as 0.35 presents about $9.7 \%$ for the average of about 3.62 , while showing that the price of zucchini has taken a growing trend year annual rate of about 0.21 presents about $9.2 \%$ from the average of about 2.22 during the study period, EP, it turns out that the price of green beans has taken a general trend growing annually by about as much as 0.38 presents about $12.2 \%$ from the average of about 3.14 , while showing that the price of potatoes has been taken as a general trend increasing annual rate of about 0.25 presents about $11.7 \%$ for 
the average of about 2.17 , it turns out that the price of the option taken a general trend growing annually by about as much as 0.23 presents about $10.3 \%$ from the average of about 2.2 EP - table (1).

Impact of the change in the exchange rate (The effect of scrolling Pass - Through Effect) on the prices of the most important vegetable crops in Egypt during the period (2000-2014):

Calculated the impact of the change in the dollar exchange rate on evolution of consumer prices for major food commodities in Egypt (onions, garlic, tomatoes, peas, green zucchini, green beans, potatoes, cucumbers) during the period (20082014) using Pass - through Effect, it has been shown from the results of table (2) that the average effect of the change in the dollar exchange rate on the evolution of the price of onions during the period (2008-2014) has reached about 4.4 EP, means that the high exchange rate of the U.S. dollar against the Egyptian pound by one pound, has led to a rise in the price of onions at about 4.4 EP on average during the period (2008-2014) . While showing that the average effect of the change in the exchange rate on the evolution of the price of garlic that reached about 11.6 EP means that the high exchange rate of the U.S. dollar against the Egyptian pound by one pound has led to a rise in the price of garlic around 11.6 EP during the period (2008-2014), where this increase is due to the increase in retail price of garlic in 2010 to about 12.93 $\mathrm{EP} / \mathrm{kg}$.

As it turns out that the average effect of the change in the exchange rate on the evolution of the price of tomatoes that were about 3.6 EP, or that high exchange rate of the U.S. dollar against the Egyptian pound by one pound has led to a rise in the price of tomatoes at about 3.6 EP, where the increase is due to the increase in retail price of tomato in 2010 to about $2.62 \mathrm{EP} / \mathrm{kg}$. While showing that the average effect of the change in the exchange rate on the evolution of the price of the pea green that reached about 2.7 EP means that the high exchange rate of the U.S. dollar against the Egyptian pound by one pound has led to a rise in the price of pea green at about 2.7 EP during the period (2008-2014).

As it turns out that the average effect of the change in the exchange rate on the evolution of the price of zucchini that was about 0.4 pound of any height that the exchange rate of the U.S. dollar against the Egyptian pound by one pound has led to a rise in the price of zucchini about 0.4 pound during the period (2008-2014). While showing that the average effect of the change in the exchange rate on the evolution of the price of green beans that were about 4.3 EP means that the rise in the exchange rate of the U.S. dollar against the Egyptian pound by one pound has led to a rise in the price of green beans at about 4.3 EP during the period (2008-2014). As it turns out that the average effect of the change in the exchange rate on the evolution of the price of potatoes reached about $1.4 \mathrm{EP}$, that any increase in the exchange rate of the U.S. dollar against the Egyptian pound by one pound has led to a rise in the price of potatoes at about 1.4 EP during the period (2008-2014).

The study was calculated scrolling Pass - Through Effect of exchange rate for consumer prices for the most important vegetable crops in Egypt without delay periods to see the impact of prices changing on vegetable crops under study, which led to test the causal relationship between variables using Granger causality test Granger Causality

Estimation of model VAR Vector Auto Regressive nonstructured to measure the impact of the change in the exchange rate on the retail prices of the most important vegetable crops in Egypt during the period (2000-2014):

Exposure to the global economy, financial crisis led to a disturbance in the performance of the Egyptian economy such as high inflation rate, which led to the importance of formulating a standard model for measuring the impact of the change in the exchange rate on the retail prices of the most important vegetable crops in Egypt during the period (20002014). The study has been use of vector autoregressive model (non- structured) (VAR) to measure the impact of the change in the exchange rate on the retail prices of the most important vegetable crops in Egypt during the study period (2000-2014) . The model is based on the study of the interactions between the exchange rate in Egypt as the dependent variable on the retail prices as independent variables for the most important vegetables crops (onions, garlic, tomatoes, green peas, zucchini, green beans, potatoes, cucumbers ) in Egypt during the period (2000-2014) through the next variables are :

E: the value of exports of the most important export crops in Egypt millions of dollars.

$\mathrm{P}_{1}$ : the retail price of onions in $\mathrm{EP} / \mathrm{kg}$. P5: the retail price of the pound zucchini / $\mathrm{kg}$.

$\mathrm{P}_{2}$ : the retail price of garlic in $\mathrm{EP} / \mathrm{kg}$. P6: the retail price of green beans in EP / $\mathrm{kg}$.

$\mathrm{P}_{3}$ : the retail price of tomatoes in $\mathrm{EP} / \mathrm{kg}$. P7: the retail price of potato pound $/ \mathrm{kg}$.

$\mathrm{P}_{4}$ : the retail price of a basket of green pound / $\mathrm{kg}$. P8: the retail price of the option in $\mathrm{EP} / \mathrm{kg}$.

\section{Test causality using Granger Causality:}

A review of the results of a causal Granger showed that the exchange rate and the prices of vegetable crops under study, where it must reject the hypothesis theme in all equations and acct the alternative hypothesis, ie, that the variables of the right side, causing a variable left end, where it was found from the test is that the variable rate and variable prices of vegetable crops ( 1 1, P2, P3, P4, P5, P6, P7, P8) realtime variables, each of which any cause - table (3).

Unit Root Test and the Lag length criteria for model variables VAR:

Been conducting Unit Root Test using a test Augmented Dickey-Fuller Test and Phillips - Perron Test, to see whether the time-series static in time or not, it was found that the prices of vegetable crops by unit roots degree $95 \%$ confidence interval for the two tests in the presence of fixed and the general trend. We are using the first difference of the time series to the presence of unit roots. For the best lag length of periods, which must be included in the model (VAR) has been relying on the values of Akaike information criterion (AIC), and the values of Schwarz Bayesian criterion (SBC), 
LR test statistic as benchmarks to test the length of periods of delay appropriate to estimate the model as is clear from the tests that the best the number of periods of delay period is the one - table (4).

A review of the results of a causal Granger showed that the prices of vegetable crops under study cause and according to the causal Granger values of the previous exchange rate with one lag period or more, however, the one lag period is the most significant of which infer causality between the exchange rate and the prices of crops search (Table 5).

\section{Test of Lag Structure purification and Lag Exclusion test:}

A review of the results of test Lag Structure for vector regression model for self- non- structured (VAR) showed that the roots of the matrix autoregressive AR roots are not outside the unit circle and thus reject the hypothesis that there basic unit roots - Table (6). While seen from the test results purification arrears Lag Exclusion model vector autoregressive is structured based on the values of Akaike information criterion (AIC), and the values of Schwarz Bayesian criterion (SBC), LR test statistic as criteria for the disposal of a number of periods showed that the best lag periods is the one period - table (7)

\section{Cross Correlation analysis between the exchange rate and form variables:}

Calculated the correlation between the exchange rate as the dependent variable and the VAR model variables as independent variables which retail prices for the most important vegetable crops (onions, garlic, tomatoes, green peas, zucchini , green beans , potatoes, cucumbers ) in Egypt during the period (2010-2014), has shown results existence of a correlation between the exchange rate and the retail prices of vegetable crops at the most important level of significance 0.01 , according to a range of lag periods amounted to about 36 periods, which increases the correlation power whenever increased the period leading and lagged period. Have been identified the periods leading which shows a stronger correlation between the exchange rate and form variables.

When the range is between (0.003) and (0.27) shows that the degree of correlation between the exchange rate and the price of onions reached about 80.5 , while when the range is between $(-0.05)$ and (0.36) shows that the degree of correlation between the exchange rate and the price of garlic amounted to about 0.821 , while when the range is between ($0.07)$ and $(0.25)$ shows that the degree of correlation between the exchange rate and the price of tomatoes amounted to about 0.804 , while when the range is between $(-0.03)$ and $(0.44)$ shows that the degree of correlation between the exchange rate The price of green peas amounted to about 0.815 , while when the range is between $(-0.03)$ and $(0.38)$ shows that the degree of correlation between the exchange rate and the price of zucchini amounted to about 0.776 , while when the range is between $(-0.07)$ and $(0.38)$ shows that the degree of correlation between the exchange rate and the price of green beans amounted to about 0.827 , while when the range is between (0.04) and ( 0.37 ) shows that the degree of correlation between the exchange rate and the price of potatoes amounted to about 0.833 , while when the range is between $(-0.03)$ and (0.42) shows that the degree of correlation between the exchange rate and the option price amounted to about 0.796 table ( 8). It is noted that the presence of a strong correlation between variables does not necessarily indicate a relationship between the slope of the variables do not reflect a causal relationship between variables, but may only reflects the existence of joint movement between variables Co-Movement

\section{Function Impulse Response:}

Function is used to respond to shocks to identify the effect of a variable shocks that can be exposed to another variable, A review of the results table (8) show that any shock in exchange rate effects are increasing the price of onions, where the percentage change monthly maximum, reaching about $6.3 \%$ at the end of the period. While the percentage change in the price of garlic fluctuated from about $12 \%$ at the beginning of the period to about $12.8 \%$ at the end of the period, also increased the percentage change in the price of tomatoes from about $(3.0 \%)$ at the beginning of the period to about $3.5 \%$ at the end of the period, while increased percentage change in the price of green peas from about $2.3 \%$ at the beginning of the period to about $6.9 \%$ at the end of the period, while the percentage change in the price of zucchini from about $2.8 \%$ at the beginning of the period to about $5.8 \%$ at the end of the period, also increased the percentage change in the price of green beans from about $2.4 \%$ at the beginning of the period to about $6.8 \%$ at the end of the period, while the percentage change in the price of potatoes from about $(2.3 \%)$ at the beginning of the period to about $5 \%$ at the end of the period, while the percentage change in option price of about $1.7 \%$ at the beginning of the period to about $4.1 \%$ at the end of the period - table ( 8), figure (1).

Figure (1) showed that any shock in the exchange rate have a positive impact in the Great during the last ten periods shown in Figure Chart, where noted a decrease or an increase in the retail prices of all vegetables (onions, garlic, tomatoes, peas, green zucchini, green beans, potatoes, cucumbers) in Egypt decrease or increase in the exchange rate, and this is what explains the impact of the global financial crisis on the continuing rise in world food prices and the impact on food prices in the Egyptian market, particularly retail prices for vegetable crops. 
Proc. of the Third Intl. Conf. Advances in Social Science, Economics and Management Study- SEM 2015

Copyright (C) Institute of Research Engineers and Doctors, USA .All rights reserved.

ISBN:978-1-63248-063-7 doi: 10.15224/978-1-63248-063-7-40

\section{Figures and Tables}

Table (1): Equations of general trend of the exchange rate and the retail price of the most important vegetable crops in Egypt during (2010-2014)

\begin{tabular}{|c|c|c|c|c|c|c|}
\hline Depend Variable & c & Average & b & $\begin{array}{c}\text { Annual } \\
\text { growth } \\
\text { rate }\end{array}$ & $\mathbf{R}^{2}$ & F \\
\hline $\begin{array}{c}\text { Dollar exchange } \\
\text { rate (pounds / } \\
\text { dollars) }\end{array}$ & 3.70 & 5.42 & 0.21 & 4.0 & 0.860 & $80.1^{*}$ \\
\hline $\begin{array}{c}\text { Onions price } \\
\text { (pounds / kg) }\end{array}$ & 0.542 & 1.91 & 0.31 & 16.1 & 0.712 & $32.2^{*}$ \\
\hline $\begin{array}{c}\text { Garlic price (pounds } \\
\text { / kg) }\end{array}$ & 0.131 & 5.51 & 0.71 & 12.8 & 0.590 & $18.7^{*}$ \\
\hline $\begin{array}{c}\text { Tomato price } \\
\text { (pounds / kg) }\end{array}$ & 0.263 & 1.80 & 0.19 & 10.7 & 0.763 & $41.9^{*}$ \\
\hline $\begin{array}{c}\text { Green peas } \\
\text { price(pounds / kg) }\end{array}$ & 0.826 & 3.62 & 0.35 & 9.7 & 0.863 & $81.9^{*}$ \\
\hline $\begin{array}{c}\text { Zucchini } \\
\text { price(pounds / kg) }\end{array}$ & 0.581 & 2.22 & 0.21 & 9.2 & 0.901 & $117.8^{*}$ \\
\hline $\begin{array}{c}\text { Green beans price } \\
\text { (pounds / kg) }\end{array}$ & 0.065 & 3.14 & 0.38 & 12.2 & 0.816 & $57.5^{*}$ \\
\hline $\begin{array}{c}\text { Potatoes } \\
\text { price(pounds / kg) }\end{array}$ & 0.145 & 2.17 & 0.25 & 11.7 & 0.734 & $35.9^{*}$ \\
\hline $\begin{array}{c}\text { Option price } \\
\text { (pounds / kg) }\end{array}$ & 0.381 & 2.20 & 0.23 & 10.3 & 0.765 & $42.2^{*}$ \\
\hline
\end{tabular}

*Significant at $0.01, \quad * *$ significant at 0.05 .

Negative numbers between brackets

Source: Collected by using from references (2), (3)

Table (2): Effect of scrolling Pass-Through Effect of exchange rate on the most important vegetable prices crop in Egypt during the period (2000-2014):

\begin{tabular}{|c|c|c|c|c|c|c|c|c|}
\hline \multirow{2}{*}{ Year } & \multicolumn{7}{|c|}{ Effect of scrolling Pass ((Pt- Pt-1)/ Pt-1)/(Et- Et-1)/ Et-1) } \\
\cline { 2 - 10 } & Onion & Garlic & Tomato & $\begin{array}{c}\text { IGreen } \\
\text { peas }\end{array}$ & Zucchini & $\begin{array}{c}\text { Green } \\
\text { beans }\end{array}$ & Potat. & Option \\
\hline $\mathbf{2 0 0 0}$ & 0.71 & 0.17 & 0.37 & 0.14 & 0.46 & 0.56 & 0.64 & 0.62 \\
\hline $\mathbf{2 0 0 1}$ & 3.59 & 6.78 & -3.52 & -0.51 & -0.43 & -1.11 & 0.63 & -1.94 \\
\hline $\mathbf{2 0 0 2}$ & 0.31 & 1.01 & 0.03 & 0.02 & 0.40 & 0.40 & 0.10 & 0.44 \\
\hline $\mathbf{2 0 0 3}$ & 1.45 & -1.01 & 1.52 & 0.10 & 0.41 & 0.12 & 1.32 & 0.06 \\
\hline $\mathbf{2 0 0 4}$ & 33.22 & -2.77 & 1.43 & 0.86 & 4.56 & 1.00 & 1.20 & 1.81 \\
\hline $\mathbf{2 0 0 5}$ & 121.8 & 118.2 & -33.07 & -14.51 & -12.47 & -9.01 & -54.3 & 35.3 \\
\hline $\mathbf{2 0 0 6}$ & 0.00 & 6.94 & 6.48 & 3.44 & 3.43 & 3.23 & 8.75 & 1.38 \\
\hline $\mathbf{2 0 0 7}$ & -7.34 & -0.10 & 9.62 & -4.10 & -0.36 & -14.51 & -5.00 & -5.93 \\
\hline $\mathbf{2 0 0 8}$ & 4.79 & 6.32 & -16.32 & -4.42 & -4.88 & -5.40 & -1.42 & -5.86 \\
\hline $\mathbf{2 0 0 9}$ & -6.91 & 25.09 & -14.77 & 11.72 & -0.83 & -3.88 & 5.89 & -3.29 \\
\hline $\mathbf{2 0 1 0}$ & 19.23 & 68.95 & 58.77 & 3.43 & 3.10 & 17.03 & 0.59 & 8.34 \\
\hline $\mathbf{2 0 1 1}$ & 4.42 & -7.41 & 0.73 & 1.57 & 8.30 & 5.07 & 2.33 & 2.31 \\
\hline $\mathbf{2 0 1 2}$ & 2.32 & -23.85 & -3.77 & 1.31 & -0.70 & 7.22 & -3.79 & 6.36 \\
\hline $\mathbf{2 0 1 3}$ & 10.45 & 10.83 & 0.87 & 1.91 & 1.52 & 0.64 & 8.86 & 5.03 \\
\hline $\mathbf{2 0 1 4}$ & -3.72 & 1.00 & -0.51 & 3.58 & -3.71 & 9.22 & -2.86 & -4.97 \\
\hline $\mathbf{2 0 0 8}$ & $\mathbf{4}$ & $\mathbf{1 1 . 5 6}$ & $\mathbf{3 . 5 7}$ & $\mathbf{2 . 7 3}$ & $\mathbf{0 . 4 0}$ & $\mathbf{4 . 2 7}$ & $\mathbf{1 . 3 7}$ & $\mathbf{1 . 1 3}$ \\
\hline $\mathbf{2 0 1 4}$ & & & & & & & & \\
\hline $\mathbf{S 0 u}$ & & & & & & \\
\hline
\end{tabular}

Source: Collected by using from references (2), (3).

Scrolling effect was calculated from the equation:

\begin{tabular}{|c|c|c|}
\hline \multirow{5}{*}{$\begin{array}{c}\text { Pass } \\
\text { Through } \\
\text { Effect }=\end{array}$} & $\mathrm{Pi}-\mathrm{Pi}_{\mathrm{t}-1}$ & \multirow{5}{*}{$\begin{array}{l}\text { Where: } \\
\mathrm{Pi} \text { : the price of the crop in year } \mathrm{t} \\
\mathrm{Pit}-1 \text { : the price of the crop in the previous year } \mathrm{t}-1 \\
\mathrm{Ei}: \text { the exchange rate of the dollar in Egyptian EP in year } \mathrm{t} \\
\text { Et-1: U.S. dollar exchange rate in the previous year } \mathrm{t}-1 \mathrm{Pi}-\mathrm{Pit}-1\end{array}$} \\
\hline & $\mathrm{Pi}_{\mathrm{t}-1}$ & \\
\hline & & \\
\hline & $\mathrm{Ei}-\mathrm{E}_{\mathrm{t}-1}$ & \\
\hline & $\mathrm{E}_{\mathrm{t}-1}$ & \\
\hline
\end{tabular}

Table (3): Results of the analysis of Granger Causality test

\begin{tabular}{|c|c|c|c|}
\hline Null Hypothesis: & Obs & F-Statistic & Prob. \\
\hline P1 does not Granger Cause E & 178 & 8.67 & 0.000 \\
\hline E does not Granger Cause $\mathrm{P}_{1}$ & & 7.52 & 0.001 \\
\hline P2 does not Granger Cause E & 178 & 3.28 & 0.041 \\
\hline E does not Granger Cause $\mathrm{P}_{2}$ & & 11.31 & 0.000 \\
\hline P3 does not Granger Cause E & 178 & 9.75 & 0.000 \\
\hline E does not Granger Cause $\mathrm{P}_{3}$ & & 5.41 & 0.005 \\
\hline P4 does not Granger Cause $\mathrm{E}$ & 178 & 4.59 & 0.012 \\
\hline E does not Granger Cause $\mathrm{P}_{4}$ & & 3.40 & 0.036 \\
\hline P5 does not Granger Cause $\mathrm{E}$ & 178 & 3.89 & 0.023 \\
\hline E does not Granger Cause $\mathrm{P}_{5}$ & & 4.87 & 0.009 \\
\hline P6 does not Granger Cause $\mathrm{E}$ & 178 & 11.22 & 0.000 \\
\hline E does not Granger Cause $\mathrm{P}_{6}$ & & 3.94 & 0.021 \\
\hline P7 does not Granger Cause $\mathrm{E}$ & 178 & 5.46 & 0.005 \\
\hline E does not Granger Cause $\mathrm{P}_{7}$ & & 6.13 & 0.003 \\
\hline P8 does not Granger Cause E & 178 & 4.55 & 0.012 \\
\hline E does not Granger Cause $\mathrm{P}_{8}$ & & 5.18 & 0.007 \\
\hline
\end{tabular}

Source: Collected and calculated using the program (EViews6) of data references (2), (3).

Table (4): Test of Lag Length vector regression model to self (VAR)

\begin{tabular}{|c|c|c|c|}
\hline $\begin{array}{c}\text { Lag } \\
\text { period }\end{array}$ & $\begin{array}{c}\text { LR test } \\
\text { statistic }\end{array}$ & $\begin{array}{c}\text { Akaike } \\
\text { information } \\
\text { criterion (AIC) }\end{array}$ & $\begin{array}{c}\text { Schwarz } \\
\text { Bayesian } \\
\text { criterion } \\
\text { (SBC) }\end{array}$ \\
\hline 0 & - & 19.900 & 20.083 \\
\hline 1 & 1642.63 & 9.092 & $10.914^{*}$ \\
\hline 2 & 194.980 & 8.675 & 12.138 \\
\hline
\end{tabular}

Source: Collected and calculated from the results of the analysis of VAR model using the program (E- Views6).

Table (5): Pairwise Granger Causality test for Vector Auto Regression model (VAR)

\begin{tabular}{|c|c|c|c|c|c|c|c|c|}
\hline Test & P1 & P2 & P3 & P4 & P5 & P6 & P7 & P8 \\
\hline Chi-sq & 7.70 & 6.21 & 8.65 & 8.69 & 6.01 & 8.75 & 17.46 & 10.33 \\
\hline Prob & 0.02 & 0.04 & 0.01 & 0.01 & 0.05 & 0.01 & 0.00 & 0.01 \\
\hline
\end{tabular}

Source: Collected and calculated from the results of the analysis of VAR model using the program (E-Views6). 
Proc. of the Third Intl. Conf. Advances in Social Science, Economics and Management Study- SEM 2015

Copyright (c) Institute of Research Engineers and Doctors, USA .All rights reserved.

ISBN:978-1-63248-063-7 doi: 10.15224/978-1-63248-063-7-40

Table (6): Lag Structure Test for Vector Auto Regressive Model (VAR)

\begin{tabular}{|c|c|}
\hline Roots & Modulus \\
\hline 0.984 & 0.984 \\
\hline 0.724 & 0.840 \\
\hline 0.724 & 0.840 \\
\hline 0.827 & 0.827 \\
\hline 0.794 & 0.794 \\
\hline 0.676 & 0.680 \\
\hline 0.676 & 0.680 \\
\hline 0.380 & 0.679 \\
\hline 0.380 & 0.679 \\
\hline 0.061 & 0.466 \\
\hline 0.061 & 0.466 \\
\hline 0.326 & 0.466 \\
\hline 0.326 & 0.466 \\
\hline-0.218 & 0.232 \\
\hline-0.218 & 0.232 \\
\hline 0.207 & 0.207 \\
\hline-0.048 & 0.053 \\
\hline-0.048 & 0.053 \\
\hline No root lies outside the unit circle & \\
\hline VAR satisfies the stability condition & \\
\hline Collected & \\
\hline and calated & \\
\hline
\end{tabular}

Source: Collected and calculated from the results of the analysis

of VAR model using the program (E-Views6).

Table (7): Lag Exclusion Test for vector Auto Regression model (VAR)

\begin{tabular}{|c|c|c|c|c|c|c|c|c|c|c|}
\hline & $\mathrm{E}$ & $\mathrm{P} 1$ & $\mathrm{P} 2$ & $\mathrm{P} 3$ & $\mathrm{P} 4$ & $\mathrm{P} 5$ & $\mathrm{P} 6$ & $\mathrm{P} 7$ & $\mathrm{P} 8$ & joint \\
\hline lag1 & 137 & 115.1 & 97.2 & 88.3 & 214.9 & 105.9 & 82.3 & 162.4 & 95.4 & 998 \\
& 0.00 & 0.00 & 0.00 & 0.00 & 0.00 & 0.00 & 0.00 & 0.00 & 0.00 & 0.00 \\
\hline lag2 & 6.9 & 7.8 & 54.3 & 37.0 & 16.2 & 18.4 & 8.2 & 29.8 & 29.8 & 241.6 \\
& 0.648 & 0.556 & 0.00 & 0.00 & 0.064 & 0.031 & 0.518 & 0.00 & 0.00 & 0.00 \\
\hline
\end{tabular}

Source: Collected and calculated from the results of the analysis of VAR model using the program (E- Views6).

Table (8): Impact of shocks in the exchange rate in response to the most important vegetable prices crops in Egypt (Impulse Response)

\begin{tabular}{|c|c|c|c|c|c|c|c|c|}
\hline Period & P1 & P2 & P3 & P4 & P5 & P6 & P7 & P8 \\
\hline $\mathbf{1}$ & -5.4 & 12.0 & -3.0 & 2.3 & 2.8 & -2.4 & -2.3 & 1.7 \\
\hline $\mathbf{2}$ & -4.7 & 23.8 & -5.0 & -0.2 & 3.1 & 0.0 & -1.8 & 5.3 \\
\hline $\mathbf{3}$ & -2.8 & 3.7 & -0.8 & 2.5 & 3.3 & 5.5 & 0.8 & 3.0 \\
\hline $\mathbf{4}$ & -0.4 & -1.8 & 4.2 & 5.5 & 2.6 & 5.0 & 2.3 & 0.6 \\
\hline $\mathbf{5}$ & 1.3 & -3.1 & 4.9 & 7.0 & 2.1 & 4.1 & 3.5 & - \\
\hline $\mathbf{6}$ & 2.9 & 1.8 & 2.9 & 7.8 & 2.7 & 4.1 & 4.6 & - \\
\hline $\mathbf{7}$ & 4.3 & 7.1 & 1.3 & 8.2 & 3.8 & 5.1 & 5.3 & 0.6 \\
\hline $\mathbf{8}$ & 5.4 & 10.8 & 1.3 & 8.1 & 4.9 & 6.2 & 5.6 & 1.9 \\
\hline $\mathbf{9}$ & 6.0 & 12.5 & 2.5 & 7.6 & 5.6 & 6.7 & 5.5 & 3.1 \\
\hline $\mathbf{1 0}$ & 6.3 & 12.8 & 3.5 & 6.9 & 5.8 & 6.8 & 5.0 & 4.1 \\
\hline
\end{tabular}

Source: Collected and calculated from the results of the analysis of VAR model using the program (E-Views6). 
Proc. of the Third Intl. Conf. Advances in Social Science, Economics and Management Study- SEM 2015

Copyright $(\odot$ Institute of Research Engineers and Doctors, USA .All rights reserved.

ISBN:978-1-63248-063-7 doi: 10.15224/978-1-63248-063-7-40

Figure (1): Impact of exchange rate shocks on the retail prices of the most important vegetable crops in Egypt

Response to Cholesky One S.D. Innovations \pm 2 S.E.

Response of $\mathrm{P} 1$ to $\mathrm{E}$

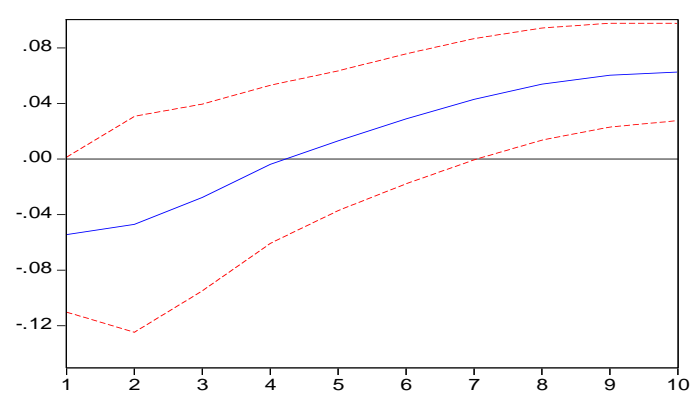

Response of P3 to Cholesky

One S.D. E Innovation

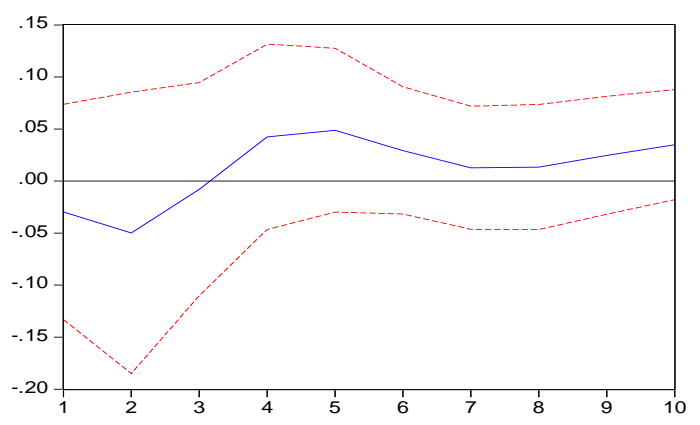

Response of P5 to Cholesky One S.D. E Innovation

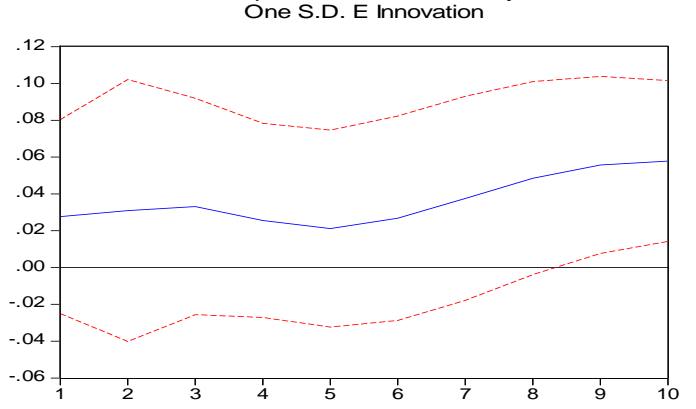

Response of P7 to Cholesky One S.D. E Innovation

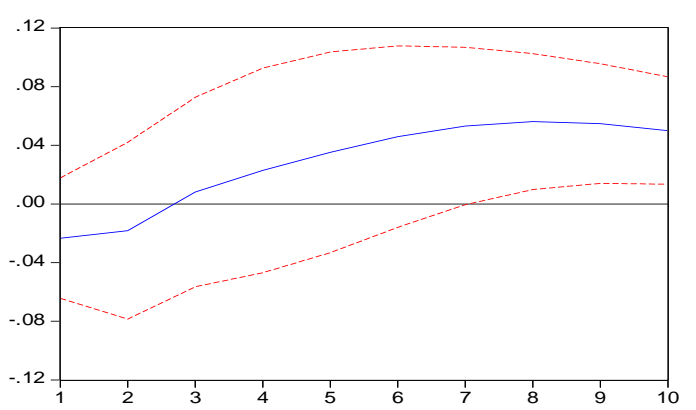

Response of P2 to Cholesky One S.D. E Innovation

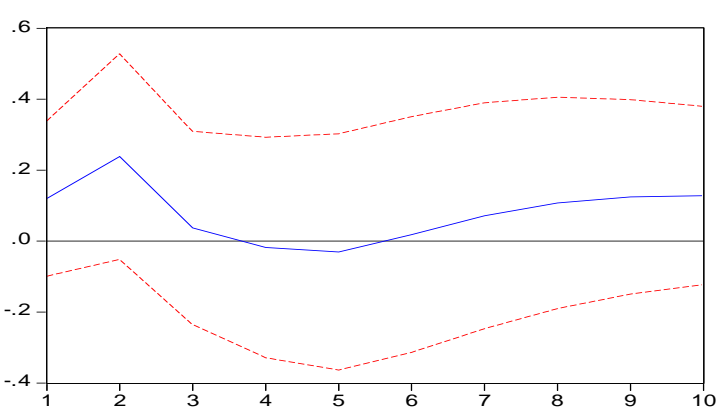
Response of P4 to Cholesky
One S.D. E Innovation

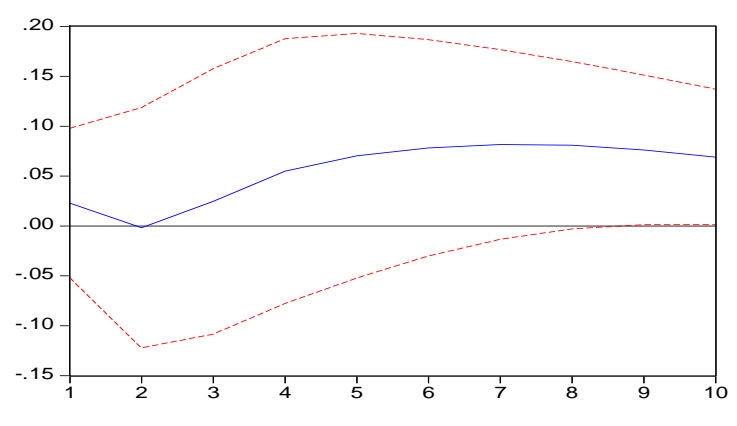

Response of P6 to Cholesky One S.D. E Innovation

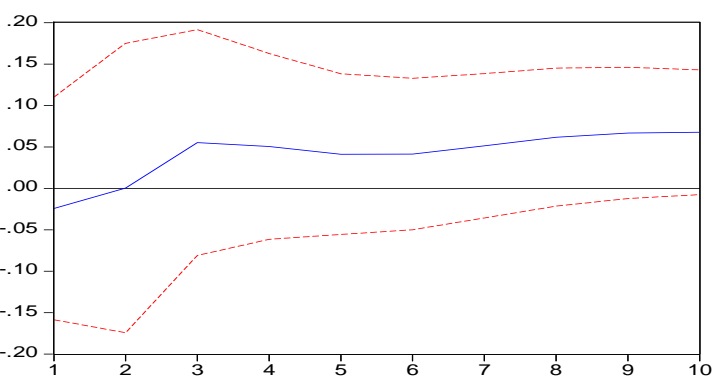

Response of $\mathrm{P} 7$ to Cholesky One S.D. E Innovation

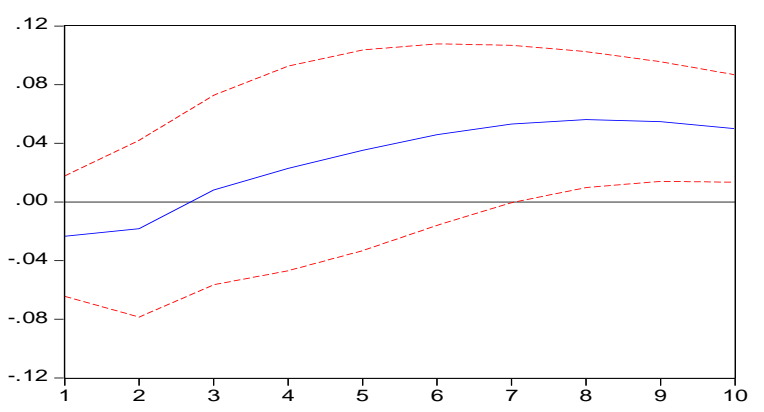

Source: Results of the analysis of VAR model using the program (E-Views6). 


\section{Conclusion}

The above study concludes: A review of the results of a causal Granger showed that the prices of vegetables (onions, garlic, tomatoes, peas, green zucchini, green beans, potatoes, cucumbers) cause according to the causal Granger values of the dollar exchange rate of one lag period and more, but the one lag period is the most significant in terms infer causality between the exchange rate of the dollar and the prices of vegetable crops under study and research.

As inferred from the account the correlation relationship was exist a correlation between the exchange rate of the Egyptian pound against the U.S. dollar and consumer prices for vegetable crops during the period (January 2010 until December 2014) at the 0.01 level of significance. While the estimate derived from a function to respond to shocks that any shock in the exchange rate has an effect on consumer prices for vegetable crops under study and research. As follows from the analysis of variance that the relative change of the exchange rate leads to the creation of shocks in consumer prices for those crops after different lag periods

\section{References}

[1] Christopher A. Sims, Tao Zha , Error Bands For Impulse Responses ,University of Saskatchewan, August 1994.

[2] David F. Hendryand Katarina Juselius ,Explaining Cointegration Analysis: PartII, Dartment of Economics, University of Copenhagen, Denmark ,2000

[3] Dickey, D.A., and W.A. Fuller, Distribution of the estimators for Autoregressive ime series: A unit root, Journal of the American Statistical Association, Vol. 74, pp. 427-31, 1979.

[4] Gaber Bassiouni \& Mamdouh Al Badry - "The effect of changing the exchange rate on prices of major food commodities in Egypt in light of the global economic crisis," $17^{\text {th }}$ Congress of Agricultural Economists, Egyptian Society of Agricultural Economics, Dokki, Cairo, from 14 to 15 October 2009.

[5] George Kapetanios, Yongcheol Shin, Testing for Cointegration in Nonlinear STAR error Correction Models, University of London , Working Paper No.497, April 2003.

[6] Granger, C.W.J., and P. Newbold, Forecasting economic time series (2nd ed.), New York: Academic Press, 1986.

[7] Jan J.J. Groen, Frank Kleibergen, Likelihood-Based Cointegration Analysis in Panels of Vector Error Correction Models ,Dartment of Quantitative Economics, University of Amsterdam ,Version: July 28, 1999 .

[8] Leamer, E.E., Vector Auto regression for casual inference? CarneiquRochester Series on Public Policy, pp. 255-303,1985.

[9] Nejib Hachicha , Exports, Export Composition And Growth: A Simultaneous Error-Correction Model For Tunisia ,International Economic Journal 101,Volume 17, Number 1, Spring 2003.

[10] Oliver Holtemoller, Structural Vector Autoregressive Models and Monetary Policy Analysis, University of Berlin, Homage: http://amor.rz.hu-berlin.de/ h32330ay ,First version: June 2001, October 2001.

[11] Richard A. Ashley, Randal J. Verbrugge ,to Difference or Not to Difference: A Monte Carlo Investigation of Inference in Vector Autoregressive Models ,Dartment of Economics, Virginia Tech (VPI) ,Division of Price and Index Number Research (3105),Bureau of Labor Statistics, October 9, 2004

[12] The effect of changing the exchange rate of the Egyptian pound on the prices of some basic food commodities in Egypt Pass through Effect, the website of the main gate of Egypt www.idsc.gov.eg
[13] Website of the Central Agency for Public Mobilization and Statistics www.capmas.gov.eg

About Author (s):

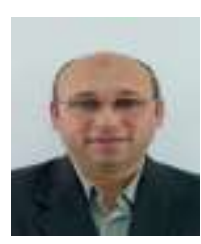

Dr. Reyad Ismaeil Moustafa Reyad is a : head of the Department of Economic \& Rural Development, Faculty of Environmental Agricultural Science, Suez Canal University.

He got his B.Sc. in 1996 at Faculty of Environmental Agricultural Science Suez Suez canal University, and got his M.SC in 2001 and $\mathrm{Ph}$. D. in 2007. He is a membership of Egyptian Association of Agricultural Economics (Cairo, Egypt). $\mathrm{He}$ published many researches in field study and participated in many local and international conferences. He has many Activities on the Total Quality Management Systems

Mamdouh Elbadry was born in Alexandria in 1969. He got his B.Sc. in 1992 at Faculty of agriculture (Saba Basha) Alexandria University, and got his M.SC in 1998 and Ph. D. in 2009 at the agriculture Alexandria University. He worked as a Specialist (19952011), Research Assistant (2011) in Agricultural Economics Research Institute, Agricultural Research Centre, Egypt, and Researcher (Doctor) (2011-until now). He is a membership of Egyptian Association of Agricultural Economics (Cairo, Egypt). He published many searches in field study and participated in many local and international Conferences. 